In the Time of Oil 



\section{In the Time of Oil}

Piety, Memory, and Social Life in an Omani Town

Mandana E. Limbert 
Stanford University Press

Stanford, California

(C)2010 by the Board of Trustees of the Leland Stanford Junior University. All rights reserved.

No part of this book may be reproduced or transmitted in any form or by any means, electronic or mechanical, including photocopying and recording, or in any information storage or retrieval system without the prior written permission of Stanford University Press.

Printed in the United States of America on acid-free, archival-quality paper

Library of Congress Cataloging-in-Publication Data

Limbert, Mandana E.

In the time of oil : piety, memory, and social life in an Omani town / Mandana E. Limbert. p. cm.

Includes bibliographical references and index.

ISBN 978-0-8047-5626-6 (cloth : alk. paper) -- ISBN 978-0-8047-5627-3 (pbk. : alk. paper)

1. Bahla' (Oman)--Social life and customs. 2. Collective memory--Oman--Bahla'. 3. Islam-Oman--Bahla'. 4. Social change--Oman--Bahla'. 5. Petroleum industry and trade--Social aspects--Oman--Bahla'. I. Title. DS247.4.B32L46 2010

953.53--dc22

201000817

Typeset by Bruce Lundquist in 10/14 Minion Pro 
For Dorothy Limbert 
